\title{
Implementasi Program Pengembangan Keprofesian Berkelanjutan Guru Melalui Peningkatan Kompetensi Pembelajaran Berbasis Zonasi
}

\author{
Warni Tune Sumar, Sartje Tune Sumar \\ 1,2 Manajemen pendidikan, Universitas Negeri Gorontalo \\ Email: warnisumar@ung.ac.id
}

\begin{abstract}
Pengembangan profesional berkelanjutan untuk guru adalah kebijakan pemerintah dalam konteks meningkatkan kualitas pendidikan, melalui peningkatan kualitas guru. Salah satu kegiatan dalam melanjutkan pengembangan profesional adalah pelatihan guru. Kegiatan pengembangan profesional guru dapat dilakukan dalam tiga bentuk, yaitu pengembangan pribadi (termasuk pelatihan fungsional dan kegiatan kolektif guru), publikasi ilmiah, dan pengembangan. Untuk memberikan kesempatan bagi para guru untuk berpartisipasi dan mempersiapkan diri mereka untuk mengalami perubahan. Program Peningkatan Kompetensi Pembelajaran adalah program yang bertujuan untuk meningkatkan kompetensi siswa melalui pelatihan guru dalam merencanakan, melaksanakan, dan mengevaluasi pembelajaran yang berorientasi pada keterampilan berpikir tingkat tinggi (HOTS). Zona untuk meningkatkan kompetensi belajar pada dasarnya adalah bagian dari strategi untuk mempercepat pengembangan pendidikan yang merata, berkualitas dan merata (Pengembangan Integrasi), melalui pengelolaan pusat kegiatan guru, kelompok kerja guru, musyawarah untuk guru mata pelajaran, dan Bimbingan dan Konseling Guru. Konsultasi, yang telah dilakukan melalui Cluster atau Rayon, terutama dalam meningkatkan kompetensi belajar.
\end{abstract}

Kata Kunci: Profesional; guru; zonasi.

\begin{abstract}
ABSTRACK
Continuing professional development for teachers is a government policy in the context of improving the quality of education, through improving the quality of teachers. One of the activities in continuing professional development is teacher training. Teacher professional development activities can be carried out in three forms, namely personal development (including functional training and teacher collective activities), scientific publications, and development. To provide opportunities for teachers to participate and prepare themselves to experience change. Learning Competency Improvement Program is a program that aims to improve student competency through teacher training in planning, implementing, and evaluating learning that is oriented to higher-order thinking skills (HOTS). The zone to improve learning competence is basically part of a strategy to accelerate the development of equitable, quality and equitable education (Integration Development), through the management of teacher activity centres, teacher working groups, deliberations for subject teachers, and Teacher Guidance and Counseling Consultations, which has been done through Clusters or Rayon, especially in improving learning competence.
\end{abstract}

Key words: Professional; Teacher; Zonasi.

(C) 2019 Warni Tune Sumar, Sartje Tune Sumar Under The License CC-BY SA 4.0

Pedagogika.fip@ung.ac.id P-ISSN : 2086-4469Ｅ-ISSN : 2716-0580 
PEDAGOGIKA

Volume 10 (Nomor 2) 2019

Hal. 84-94

PENDAHULUAN

Pendidikan merupakan suatu proses

yang sangat strategis dalam mencerdaskan

kehidupan bangsa, sehingga harus dilakukan

secara profesional. Oleh sebab itu, guru sebagai salah satu pelaku pendidikan haruslah seorang yang profesional. Untuk itu, sebagai bentuk aktualisasi tugas guru sebagai tenaga profesional maka pemerintah melalui Kementerian Pendidikan dan Kebudayaan sebagaimana diamanatkan oleh UndangUndang Nomor 20 Tahun 2003 tentang Sistem Pendidikan Nasional, Undang-Undang Nomor 14 Tahun 2005 tentang Guru dan Dosen dan Peraturan Pemerintah Nomor 13 Tahun 2005 tentang Standar Nasional Pendidikan akan memfasilitasi guru untuk dapat mengembangkan keprofesiannya secara berkelanjutan.

Dalam meningkatkan kualitas pembelajaran dan kualitas lulusan dalam hal ini peserta didik tidak terlepas dari peran Guru Profesional. Guru Profesional memegang peranan yang sangat penting dalam menentukan prestasi peserta didik. Penelitian menunjukkan bahwa $30 \%$ prestasi peserta didik ditentukan oleh faktor guru. Untuk senantiasa menjaga profesionalitas, guru harus senantiasa meng-update dirinya dengan melakukan program

pengembangan keprofesian berkelanjutan. Sebelumnya, Ditjen GTK mengembangkan Program Pengembangan Keprofesian Berkelanjutan yang didasarkan pada Hasil Uji Kompetensi Guru (UKG), berfokus pada peningkatan kompetensi guru khususnya kompetensi Pedagogi dan Profesional, maka Program PKP Berbasis Zonasi ini lebih berfokus pada upaya memintarkan siswa melalui pembelajaran berorientasi keterampilan berpikir tingkat tinggi. Begitu dominannya peran komunitas guru dan tenaga kependidikan pada program PKP berbasis zonasi ini menuntut seluruh guru terdaftar dan terlibat aktif di komunitas sesuai jenjang masing-masing.

Salah satu upaya Kementerian Pendidikan dan Kebudayaan melalui Direktorat Jenderal Guru dan Tenaga Kependidikan (Ditjen GTK) untuk meningkatkan kualitas pembelajaran yang bermuara pada peningkatan kualitas siswa adalah menyelenggarakan Program Peningkatan Kompetensi Pembelajaran (PKP).Untuk meningkatkan efisiensi, efektifitas, serta pemerataan mutu pendidikan, maka pelaksanaan Program PKP mempertimbangkan pendekatan kewilayahan, atau dikenal dengan istilah zonasi. Melalui langkah ini, pengelolaan Pusat Kegiatan Guru (PKG) TK, kelompok kerja guru (KKG) SD, 


\section{PEDAGOGIKA}

Volume 10 (Nomor 2) 2019

\section{Hal. 84-94}

atau musyawarah guru mata pelajaran (MGMP) SMP/SMA/SMK, dan musyawarah guru bimbingan dan konseling (MGBK), yang selama ini dilakukan melalui Gugus atau Rayon, dapat terintegrasi melalui zonasi pengembangan dan pemberdayaan guru. Zonasi memperhatikan keseimbangan dan keragaman mutu pendidikan di lingkungan terdekat, seperti status akreditasi sekolah, nilai kompetensi guru, capaian nilai rata-rata UN/USBN sekolah, atau pertimbangan mutu lainnya. Program Pengembangan Keprofesian Berkelanjutan melalui Peningkatan Kompetensi Pembelajaran Berbasis Zonasi merupakan salah satu upaya Kementerian Pendidikan dan Kebudayaan melalui Direktorat Jenderal Guru dan Tenaga Kependidikan (Ditjen GTK) untuk meningkatkan kualitas pembelajaran dan meningkatkan kualitas lulusan. Program ini dikembangkan mengikuti arah kebijakan Kemendikbud yang menekankan pada pembelajaran berorientasi pada keterampilan berpikir tingkat tinggi atau Higher Order Thinking Skills (HOTS). Keterampilan berpikir tingkat tinggi adalah proses berpikir kompleks dalam menguraikan materi, membuat kesimpulan, membangun representasi, menganalisis dan membangun hubungan dengan melibatkan aktivitas mental yang paling dasar yang sebaiknya dimiliki oleh seorang guru professional.

Tantangan profesi guru dari waktu ke waktu terus bergerak secara dinamis. Untuk mampu menghadapi dan menjawab tantangan masa depan tersebut, guru harus mampu menyesuaikan diri. Penyesuaian diti itu, bisa dilakukan dengan melaksanakan program PKB secara konsisten dan berkesinambungan. Apabila tidak, guru tidak akan mampu memelihara pengetahuan dan kompetensi lainnya untuk dapat menunjang pelaksanaan tugas, fungsi dan peranan secara profesional. Dengan sendirinya, guru seperti itu akan tergilas oleh perubahan zaman. Itulah sebabnya dalam buku Pedoman Pengelolaan PKB yang diterbitkan oleh Kementrian Pendidikan Nasional (2011), disebutkan bahwa program PKB "diarahkan untuk dapat memperkecil jarak antara pengetahuan, keterampilan, kompetensi sosial dan kepribadian yang mereka miliki sekarang dengan apa yang menjadi tuntutan ke depan berkaitan dengan profesinya itu.

Program Peningkatan Kompetensi Pembelajaran, selanjutnya akan disingkat dengan Program PKP, merupakan program yang bertujuan untuk meningkatkan kompetensi siswa melalui pembinaan guru dalam merencanakan, melaksanakan, sampai 
PEDAGOGIKA

Volume 10 (Nomor 2) 2019

Hal. 84-94

dengan mengevaluasi pembelajaran yang berorientasi pada keterampilan berpikir tingkat tinggi (Higher Order Thinking Skills/HOTS). Program ini merupakan bagian dari program Pengembangan Keprofesian Berkelanjutan yang diamanatkan oleh Undang-Undang Nomor 14 Tahun 2005 tentang Guru dan Dosen serta Peraturan Menteri Pendayagunaan Aparatur Negera dan Reformasi Birokrasi Nomor 16 Tahun 2009 tentang Jabatan Fungsional Guru dan Angka Kreditnya. Pengembangan Keprofesian Berkelanjutan (PKB) adalah pengembangan kompetensi guru yang dilaksanakan sesuai dengan kebutuhan, bertahap, berkelanjutan untuk meningkatkan keprofesiannya. Pada Program PKB terdahulu yang dikembangkan oleh Ditjen GTK sebelumnya, yang didasarkan pada hasil Uji Kompetensi Guru, berfokus pada peningkatan kompetensi guru khususnya kompetensi pedagogi dan profesional. Sedangkan Program PKP lebih berfokus pada upaya mencerdaskan siswa melalui pembelajaran berorientasi keterampilan berpikir tingkat tinggi.

Zona peningkatan kompetensi pembelajaran pada hakikatnya merupakan bagian dari strategi percepatan pembangunan pendidikan yang merata, berkualitas, dan berkeadilan (Integrasi Pembangunan), melalui pengelolaan pusat kegiatan guru (PKG), kelompok kerja guru (KKG), musyawarah guru mata pelajaran (MGMP), dan Musyawarah Guru Bimbingan dan Konseling (MGBK), yang selama ini dilakukan melalui Gugus atau Rayon, khususnya dalam peningkatan kompetensi pembelajaran, yang terintegrasi secara vertikal dari Satuan Pendidikan, Kabupaten/Kota, Provinsi, dan Pusat sesuai dengan kewenangan masingmasing, yang berkesinambungan dari Pendidikan Anak Usia Dini, Pendidikan Dasar.

Sejalan dengan hal di atas di atas, zona peningkatan kompetensi pembelajaran secara umum bertujuan untuk meningkatkan kompetensi siswa melalui pembinaan guru dalam merencanakan, melaksanakan sampai dengan mengevaluasi pembelajaran yang berorientasi pada keterampilan berpikir tingkat tinggi (Higher Order Thinking Skills/HOTS), dan secara khusus untuk : a) mewujudkan pemerataan pendidikan yang berkualitas dan berkeadilan, b) meningkatkan efisiensi dan efektifitas peningkatan kompetensi pembelajaran, karena kegiatan dilakukan secara terintegrasi dalam satu area wilayah dengan mempertimbangkan jarak, akses, dan volume guru yang ikut serta, c) memudahkan dalam melakukan pemetaan

\section{Pedagogika.fip@ung.ac.id P-ISSN : 2086-4469 E-ISSN : 2716-0580}




\section{PEDAGOGIKA}

Volume 10 (Nomor 2) 2019

\section{Hal. 84-94}

kompetensi, kinerja, serta aktivitas guru, d) memudahkan dalam melakukan pembinaan terhadap program peningkatan kompetensi guru sesuai dengan hasil pemetaan yang dilakukan, dan e) memudahkan dalam melakukan supervisi dan koordinasi peningkatan kompetensi pembelajaran.

Penetapan zona peningkatan kompetensi pembelajaran dilakukan dengan mempertimbangkan rambu-rambu berikut: a) Penetapan zona didasarkan pada pengklasifikasian setiap Satuan Pendidikan menurut definisi/tema zonasi yang akan disusun. b) Penentuan sekolah nominasi pusat zona mempertimbangkan indikator skala nasional, yaitu Akreditasi Sekolah, serta indikator kontrol yang mencakup hasil Ujian Nasional (UN), Uji Kompetensi Guru (UKG), dan Hasil Penjaminan Mutu Pendidikan (PMP). Pada tahap ini, pertimbangan terhadap dukungan sarana dan prasarana dan dukungan peningkatan kompetensi guru menjadi pertimbangan utama. Pertimbangan terhadap dukungan sarana dan prasarana harus mempertimbangkan kelayakan ruang kelas, laboratorium komputer dan laboratorium lainnya, sumber listrik, internet, pelaksana UNBK, sanitasi, perpustakaan, dan sarana pendukung lainnya. Sementara itu, untuk pendukung proses belajar mengajar harus mempertimbangkan faktor-faktor guru yang sudah berkualifikasi, bersertifikasi, guru yang mengajar minimal 24 jam, serta faktor lainnya. c) Perancangan program peningkatan kompetensi pembelajaran yang ada di zona yang telah ditetapkan harus mempertimbangkan karakteristik satuan pendidikan, baik jarak, akses, maupun jumlah dan sebaran guru. d. Pemantauan terhadap wilayah-wilayah zonasi melalui pemberdayaan PKG/KKG/MGMP/ MGBK dengan sekolah pusat zona sebagai basis kelompok/zona.

Komunitas merupakan ujung tombak wadah untuk berbagi dan mencari solusi mengenai masalah-masalah pendidikan yang dihadapi guru di daerah masing-masing. Program PKP Berbasis Zonasi ini diharapkan dapat menghidupkan dan menggairahkan kegiatan-kegiatan komunitas dengan lebih bersemangat.

Melalui

PKG/KKG/MGMP/MGBK, pemerataan kualitas pendidikan di seluruh Indonesia diharapkan dapat segera tercapai. Hasil UN tahun 2018 menunjukkan bahwa siswa-siswa masih lemah dalam keterampilan berpikir tingkat tinggi (Higher Order Thinking Skill) seperti menalar, menganalisa, dan mengevaluasi. Oleh karena itu siswa harus dibiasakan dengan soal-soal dan pembelajaran yang berorientasi kepada 


\section{PEDAGOGIKA}

Volume 10 (Nomor 2) 2019

\section{Hal. 84-94}

keterampilan berpikir tingkat tinggi (Higher Order Thinking Skill) agar terdorong kemampuan berpikir kritisnya. Program Pengembangan Keprofesian Berkelanjutan (PKB) ini diarahkan untuk dapat memperkecil jarak antara pengetahuan, keterampilan, kompetensi sosial, dan kepribadian yang mereka miliki sekarang dengan apa yang menjadi tuntutan ke depan berkaitan dengan profesinya itu. Sesuai dengan amanat Peraturan Menteri Negara Pemberdayaan Aparatur Negara dan Reformasi Birokrasi Nomor 16 Tahun 2009 tentang Jabatan Fungsional Guru dan Angka Kreditnya, PKB diakui sebagai salah satu unsur utama selain kegiatan pembelajaran/pembimbingan dan tugas tambahan lain yang relevan dengan fungsi sekolah/madrasah yang diberikan angka kreditnya untuk pengembangan karier guru khususnya dalam kenaikan pangkat/jabatan fungsional guru. Harapannya melalui kegiatan PKB akan terwujud guru yang profesional yang bukan hanya sekadar memiliki ilmu pengetahuan yang kuat, tuntas, dan tidak setengah-setengah, tetapi tidak kalah pentingnya juga memiliki kepribadian yang matang, kuat, dan seimbang. Dengan penguasaan ilmu pengetahuan dan teknologi yang kuat, tuntas, dan tidak setengahsetengah serta kepemilikan kepribadian yang prima, maka diharapkan guru terampil membangkitkan minat peserta didik kepada ilmu pengetahuan dan teknologi melalui penyajian layanan pendidikan yang bermutu.

Pengelolaan zona peningkatan kompetensi pembelajaran dilakukan melalui tahapan sebagai berikut: a) Menetapkan wilayah zona peningkatan kompetensi pembelajaran berdasarkan radius terdekat dengan sekolah yang akan dijadikan tempat kegiatan Program PKP Berbasis Zonasi yang berada di wilayah zonasi yang telah ditentukan. b) Melakukan analisis jumlah guru sesuai bidang tugas yang diampu di masingmasing zona. c) Menetapkan PKG, KKG, MGMP, dan MGBK berdasarkan jumlah keanggotaan pada rentang 10-20 orang per kelompok. d) Melakukan analisis kebutuhan guru inti untuk masing-masing zona. e) Melakukan analisis kebutuhan dan waktu pelaksanaan pembekalan guru inti.

Manfaat Program PKP Berbasis Zonasi adalah sebagai berikut: a) membiasakan guru untuk membuat pembelajaran yang berorientasi pada keterampilan berpikir tingkat tinggi mulai dari perencanaan, pelaksanaan hingga penilaiannya; b) membiasakan siswa untuk berpikir tingkat tinggi sehingga dapat meningkatkan kompetensinya; c) memberikan

\section{Pedagogika.fip@ung.ac.id P-ISSN : 2086-4469 E-ISSN : 2716-0580}


PEDAGOGIKA

Volume 10 (Nomor 2) 2019

\section{Hal. 84-94}

acuan kepada kepala sekolah dalam pelaksanaan supervisi akademik; dan d) memberikan acuan kepada pengawas sekolah dalam pelaksanaan supervisi akademik dan manajerial. Program ini merupakan salah satu pendukung program Pengembangan Keprofesian Berkelanjutan yang lebih berfokus pada upaya memintarkan siswa melalui pembelajaran berorientasi keterampilan berpikir tingkat tinggi. Dengan mempertimbangkan pendekatan kewilayahan, atau dikenal dengan istilah zonasi, maka program ini dilakukan dengan berbasis zonasi, selanjutnya di sebut program peningkatan kompetensi pembelajaran berbasis zonasiadalah sebagai berikut:

- Salah satu upaya yang dilakukan pemerintah tersebut adalah dengan melaksanakan program Peningkatan Kompetensi Pembelajaran (PKP) Berbasis Zonasi.
- Program

zonasi dikembangkan mengikuti arah Kemendikbud yang pembelajaran Keterampilan Berpikir Tingkat Tinggi atau Higher Order Thinking Skills (HOTS).
PKP berbasis dengan kebijakan menekankan berorientasi seorang guru harus terus meningkatkan profesionalismenya melalui berbagai kegiatan yang dapat meningkatkan kemampuannya dalam mengelola pembelajaran maupun kemampuan lain dalam meningkatkan keterampilan peserta didik yang memiliki keterampilan belajar yang melengkapi keterampilan dalam mencari pengetahuan

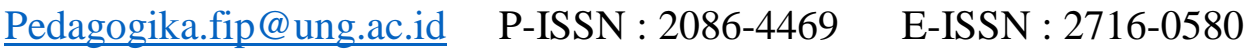




\section{PEDAGOGIKA}

Volume 10 (Nomor 2) 2019

\section{Hal. 84-94}

(belajar untuk mengetahui), keterampilan dalam mengembangkan jati diri (belajar menjadi), keterampilan dalam menjalankan tugas-tugas tertentu (belajar untuk melakukan), dan keterampilan untuk dapat hidup berdampingan dengan semua orang harmonis (belajar untuk hidup bersama). Pengembangan keprofesian berkelanjutan harus dilakukan berdasarkan kebutuhan guru yang bersangkutan. Kebutuhan yang dimaksud adalah kebutuhan untuk mencapai dan/atau meningkatkan kompetensinya di atas standar kompetensi profesi guru. Hal ini nantinya juga sekaligus berimplikasi pada perolehan angka kredit untuk kenaikan pangkat/jabatan fungsional guru. PKB adalah bentuk pembelajaran yang berkelanjutan bagi guru yang merupakan wahana utama yang membawa perubahan yang perlu diperhatikan oleh para siswa. Dengan demikian, semua siswa diharapkan dapat memiliki pengetahuan yang lebih, memiliki pengetahuan yang lebih baik, dan memahami yang terkait dengan materi ajar serta mampu memfasilitasi apa yang mereka dapatkan dan mampu melakukannya. PKB meliputi berbagai cara dan / atau sedang membahas guru setelah mendapat pendidikan dan / atau pelatihan awal sebagai guru. PKB ukung guru untuk meningkatkan dan meningkatkan standar mereka dalam bidang yang terkait dengan bidang pekerjaan sebagai profesi.

\section{METODE PENELITIAN}

Metode Penelitian yang dilakukan adalah dengan mengumpulkan data berupa informasi melalui dokumen-dokumen, baik dokumen tertulis, foto, maupun dokumen elektronik yang dapat mendukung proses penulisan.

\section{HASIL DAN PEMBAHASAN}

Kebutuhan pelatihan dapat diperoleh dengan menganalisa kesenjangan antara tujuan yang akan dicapai dan kondisi saat ini. Dari analisis ini dapat diketahui potensi masalah yang dapat menghambat ketercapaian tujuan. Dalam pengembangan kepro- fesian berkelanjutan guru, tujuan akhirnya adalah guru yang efektif (Luneta, 2012). Dari berbagai penelitian, Luneta (2012) meng- identifikasi beberapa alasan pengembangan keprofesian guru dengan peran utama mengarahkan pada guru yang efektif. Alasan yang diajukan oleh Luneta (2012) adalah sebagai berikut: (1) Untuk memperbaiki ketrampilan unjuk kerja individu guru atau kelompok tenaga kependidikan melalui pendekatan yang konstruktivistik. Guru dituntut dan diperlakukan sebagai pembelajar aktif, yang dilibatkan dalam tugas-tugas konkret yaitu pengajaran, penilaian, observasi, dan refleksi. (2) Untuk

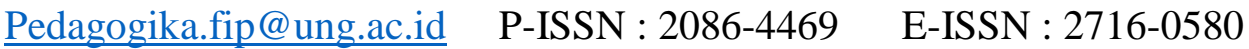




\section{PEDAGOGIKA}

Volume 10 (Nomor 2) 2019

\section{Hal. 84-94}

meningkatkan unjuk kerja indi- vidual guru dalam rangka pengembangan karir dan promosi jabatan. (3) Untuk mengembangkan pengetahuan profesional dan pemahaman individual guru. Guru disadarkan hakekatnya seba gai praktisi yang reflektif, yang memasuki profesi dengan pengetahuan tertentu, namun memperoleh pengetahuan dan pengalaman baru dibandingkan pengetahuan yang telah dimilikinya. (4) Untuk memberikan kesempatan kepada guru berpartisipasi dan mempersiapkan diri mengalami perubahan. Hal ini dapat diperoleh dengan guru belajar terus me- nerus dan pengembangan diri dilakukan dalam proses yang panjang. Pengem- bangan diri dapat diperoleh melalui suatu rangkaian pengalaman yang berkaitan dan bukan pengalaman yang hanya sekali dialami. Akan lebih efektif jika guru didampingi untuk melakukan pengaitan antara pengetahuan yang telah dimiliki dengan pengalaman yang baru diperoleh. Dukungan yang teratur kepada guru dibutuhkan sebagai katalisator penyaluran dari berbagai persoalan yang dihadapi guru selama proses perubahan.

Dengan merujuk kepada keempat alasan yang dikemukakan oleh Luneta (2012), maka analisis kebutuhan pelatihan untuk konteks Indonesia dapat dijelaskan untuk memperbaiki unjuk kerja guru. Dalam konteks Indonesia unjuk kerja guru diperoleh dari data Penilaian Kinerja Guru (PKG). Dalam Pedoman Pelaksanaan Penilaian Kinerja Guru (PK Guru) tahun 2011 Secara umum, PK GURU memiliki 2 fungsi utama yaitu: untuk menilai kemampuan guru dalam menerapkan semua kompetensi dan keterampilan yang diperlukan pada proses.pembelajaran, pembimbingan, atau pelaksanaan tugas tambahan yang relevan dengan fungsi sekolah/madrasah; untuk menghitung angka kredit yang diperoleh guru atas kinerja pembelajaran, pembimbingan, atau pelaksanaan tugas tambahan yang relevan dengan fungsi sekolah/madrasah yang dilakukannya pada tahun tersebut.

\section{KESIMPULAN}

Berdasarkan pembahasan diatas dapat disimpulkan bahwa implementasi program pengembangan keprofesian berkelanjutan guru melalui peningkatan kempotensi pembelajaran berbasis zonasi adalah sebagai berikut:

PKB adalah suatu bentuk pembelajaran berkelanjutan bagi guru yang merupakan suatu jalan utama dalam upaya mengubah-perubahan yang berkaitan dengan peserta didik, sehingga para siswa diharapkan 
PEDAGOGIKA

Volume 10 (Nomor 2) 2019

Hal. 84-94

memiliki pengetahuan, keterampilan/

keterampilan yang lebih, dan mampu menggunakan materi yang terkait. Dengan adanya PKB guru mampu menarik minat peserta didik khusus dalam ilmu pengetahuan dan teknologi.

Menjadi seorang guru yang sangat membutuhkan keterampilan / kemampuan dalam proses peningkatan pendidikan, guru juga harus memiliki karakter khusus dalam mengajar. PKB merupakan wadah pencocokan dan penawaran untuk guru. Karena PKB memberikan suatu pembelajaran yang berkelanjutan bagi guru yang merupakan wahana utama yang membawa perubahan yang diinginkan peserta didik.

Dalam meningkatkan efisiensi, efektifitas, serta pemerataan mutu pendidikan, maka pelaksanaan Program PKP mempertimbangkan pendekatan kewilayahan, atau dikenal dengan istilah "Zonasi". Melalui langkah ini, Pengelolaan Pusat Kegiatan Guru (PKG) TK, Kelompok Kerja Guru (KKG) SD, atau Musyawarah Guru Mata Pelajaran (MGMP) SMP/SMA/SMK, dan Musyawarah Guru Bimbingan dan Konseling (MGBK), yang selama ini dilakukan melalui Gugus atau Rayon, dapat terintegrasi melalui Zonasi Pengembangan dan Pemberdayaan Guru.
Sistem Zonasi mempertimbangkan

keseimbangan dan keragaman mutu pendidikan di lingkungan terdekat seperti akreditasi sekolah, nilai kompetensi guru, capaian nilai rata-rata UN/USBN Sekolah, atau pertimbangan mutu lainya.

\section{REFERENSI}

Akuntono, Indra.2012. Rata -ata Hasil Uji Kompetensi guru Masih Rendah. http:/ /edukasi.kompas.com/ read/2012/03/ 16/ 17455390/Rata.rata. Hasil Uji. Kompetensi. Guru Masih Rendah. Diakses 14 Maret 2014

Badan BPSDMPK \& PMP.2014. Sistem Pembinaan Guru Profesional. Tersedia dalam http://www.slideshare.net/ kie242004/profesi-guru-42111282.

Diakses 28 November 2014

Brinkerhoff, Robert O. Clarifying and Directing Impact Evaluation. Dalam Brown, Stephen M. dan Constance J. Seidner.1998. Evaluating Corporate Training: Models and Issues. New York: Springer Science + Business Media

Craft, Anna.2000. Continuing Professional Development: A Practical Guide for Teachers and Schools: Taylor \& Francis e-Library

Danim, S. 2002. Inovasi Pendidikan, Dalam Upaya Peningkatan Profesionalisme Tenaga Kependidikan (Bandung: Pustaka Setia,)

Furjanic, Sheila W \& Laurie A Trotman. 2000.Turning Training into Learning. New York: AMACOM

Jalal, Fasli dan Dedi Supriadi (ed). 2001. Reformasi Pendidikan Dalam Konteks

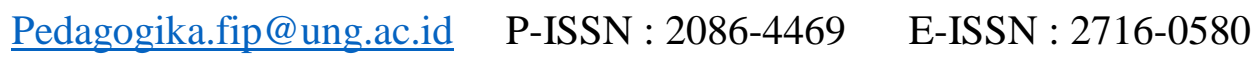


PEDAGOGIKA

Volume 10 (Nomor 2) 2019

Hal. 84-94

Otonomi Daerah. Yogyakarta: Adicita Karya Nusa.

Herawan, Endang dan Nani Hartini. Manajemen Tenaga Pendidik dan Kependidikan. Dalam Tim Dosen Administrasi Pendidikan Universitas Pendidikan Indonesia.2014. Manajemen Pendidikan. Bandung: Alfabeta

Indarti, Sri dan Rispantyo. 2009.Pengaruh Pendidikan Pelatihan, Motivasi Kerja dan Lingkungan Kerja Terhadap Kinerja Guru Sekolah Dasar. Jurnal Manajemen Sumberdaya Manusia. Volume 3 No. 2 Desember 2009.

Kemendiknas, 2011. Pedoman Pengelolaan

Pengembangan Keprofesian Berkelanjutan (PKB), Jakarta.

Kementrian Pendidikan Nasional. 2011. Pedoman Penilaian Kinerja Guru (PK Guru). Jakarta: Kementrian Pendidikan Nasional

Suparlan, 2006. Guru Sebagai Profesi. (Yogyakarta: Hikayat Pedoman Pengembangan Pengembangan Keprofesian Berkelanjutan (PKB), Kemendiknas, Jakarta 2011. 